\title{
Prevalence of Sepsis and Possible Severe Bacterial Infection among Neonates in Nepal
}

\author{
Gambhir Shrestha, ${ }^{1}$-Rashmi Mulmi, ${ }^{2}$ Nibaran Joshi, ${ }^{3}$ Parashu Ram Shrestha ${ }^{1}$ \\ ${ }^{1}$ Child Health Division, Department of Health Services, Teku, Kathmandu, ${ }^{2}$ School of Public Health \\ and Community Medicine, B.P Koirala Institute of Health Sciences, Sunsari, ${ }^{3}$ Kanti Children's Hospital, \\ Kathmandu, Nepal
}

\section{ABSTRACT}

Nepal lacks adequate data on the prevalence of sepsis and Possible Severe Bacterial Infection (PSBI) among neonates.
Thus, this systematic review was designed to estimate the prevalence of neonatal sepsis and PSBI status in Nepal. We
searched PubMed and Nepal Journal Online for relevant studies on PSBI and neonatal sepsis published from 2006 to
2016. The eligibility criteria included those studies done in Nepal, evaluating the prevalence of PSBI/neonatal sepsis
with denominators as the population at risk that is either total live births or total cases evaluated. Altogether, four
studies met the review criteria, out of which three were hospital-based and one community-based. There is a vast
difference in prevalence rate between hospital-based (2-4\%) and community-based (9\%) studies. Two studies used
haematological scoring system and blood culture to base their diagnosis; one used signs and symptoms for PSBI while
the other did not mention the diagnostic criteria. This systematic review suggests that though neonatal sepsis poses
a big problem, it lacks a significant number of related studies. There is a need to conduct a nationwide survey on the
prevalence of sepsis and PSBI among neonates, which will help to develop health policy.
Keywords: Nepal; neonates; possible severe bacterial infection; sepsis.

\section{INTRODUCTION}

Infection is the most common cause of neonatal mortality worldwide. ${ }^{1-6}$ Possible Severe Bacterial Infection (PSBI) is a clinical syndrome used in the Integrated Management of Neonatal and Childhood Illness (IMNCI) package referring to a sick young infant who requires urgent referral to hospital. $^{7}$ Sepsis is defined as life-threatening organ dysfunction caused by a dysregulated host response to infection. ${ }^{8}$ Clinical algorithms have been developed in Nepal to direct the treatment of neonates and young children identified with PSBI as in the WHO guidelines of the Integrated Management of Childhood Illness. 9, 10

After a decade of struggle, the neonatal mortality has declined from 33 to 21 deaths per 1000 live births in Nepal as reported in the most recent Nepal Demographic Health Survey 2016 (NDHS). ${ }^{11}$ WHO's Every Newborn Action Plan (ENAP) sets a target of 10 or fewer neonatal deaths per 1000 live birth in every country by $2035 .{ }^{12}$ Nepal is committed to achieving this target and has set up some strategies such as the upgrade of government hospitals, implementation of free newborn care services and development of training materials and capacity building of health workers. ${ }^{13,14}$
This study aimed to review the literature available to find out the prevalence of PSBI and/or neonatal sepsis which will help the policy makers to make appropriate plans and policy for the prevention and management of the newborn with infection.

\section{METHODS}

For the purpose of this systematic review, a comprehensive literature search using the search engines PUBMED and Nepal Journal Online (NEPJOL) was performed. Keywords used in the search included "possible severe bacterial infection" AND “newborn/neonates" AND “Nepal”, "possible severe bacterial infection among newborn in Nepal”, "neonatal sepsis” AND “Nepal”, "neonatal sepsis in Nepal”, "neonat* sepsis" AND "Nepal”. For uniformity in hospital-based and community-based studies, PSBI cases of only neonates (0-28days) were included.

Any empirical study that explored PSBI or neonatal sepsis in Nepal was considered for possible inclusion in the review. The inclusion criteria in this review were: studies have to be (a) conducted during the period 20062016, and (b) a denominator for the population at risk had to be available as a total number of live births or 
total cases evaluated. We did not exclude studies on the basis of their method of case ascertainment.

Two reviewers (GS and RM) independently searched for the titles and abstracts and selected the studies that were relevant. Both reviewers read the titles, abstracts and full texts of the selected studies to verify that they matched the inclusion criteria. Any disagreement among the two reviewers was resolved through discussion and the final decision to be included in the study was taken by the third reviewer (PRS).

Community-based studies diagnosed PSBI on the basis of signs and symptoms and hospital-based studies diagnosed neonatal sepsis on the basis of signs and symptoms as well as investigations. Hence, the studies were categorised as community and hospital-based. We initially planned to find out the risk factors for neonatal sepsis/PSBI cases but most of the studies were descriptive in nature and very few studies have analysed risk factors, thus we had to limit ourselves to prevalence study.

The protocol of this systematic review was registered at PROSPERO on 17 May 2017. The registration number for this review is CRD42017065996 available from [Link]

\section{RESULTS}

The initial search resulted in the identification of a total of 107 potentially relevant studies. Review of the titles and abstracts of identified articles resulted in the selection of 32 studies that met the inclusion criteria. The full text was retrieved for all of these 32 articles and two independent reviewers read these articles to determine suitability for inclusion. This review resulted in narrowing the set of articles down to four (Figure 1).

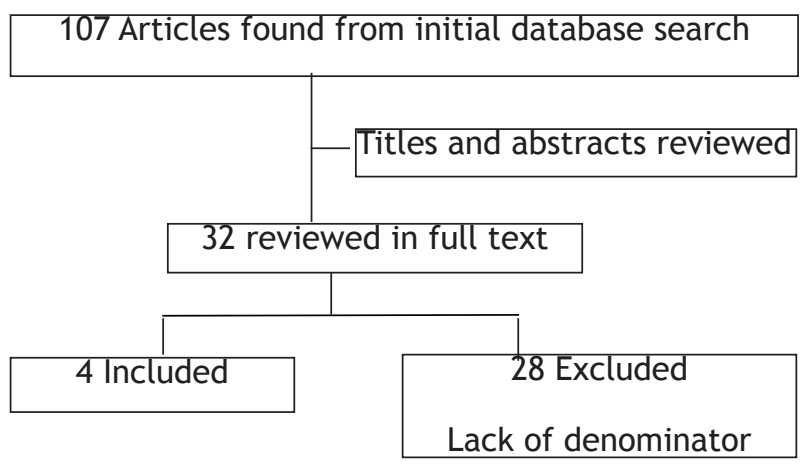

\section{Figure 1. Flowchart of the studies identified and the process of selection of the studies.}

All the four studies included in the review were of crosssectional design. Two studies have unclear denominators. However, due to a scant number of studies that fit in this review we have to include them.

Among four studies, three were hospital-based viz. Paropakar Maternity and Women's Hospital (Kathmandu), Nepal Medical College (Kathmandu) and Patan Hospital (Patan). ${ }^{15-17}$ One study was community-based and was conducted in Morang district. ${ }^{18}$ Two studies used haematological scoring system and blood culture to base their diagnosis; one used signs and symptoms for PSBI according to MINI algorithms while one study did not mention the diagnostic criteria (Table 1).

\begin{tabular}{|c|c|c|c|c|c|c|c|}
\hline Authors & Study site & Study sample & Diagnosis & $\begin{array}{l}\text { Period } \\
\text { of data } \\
\text { collection }\end{array}$ & Study type & $\begin{array}{l}\text { Prevalence } \\
\text { of sepsis/ } \\
\text { PSBI }\end{array}$ & $\begin{array}{l}\text { Significant } \\
\text { risk factors if } \\
\text { identified }\end{array}$ \\
\hline $\begin{array}{l}\text { Thapa } \\
\text { B et al. } \\
\text { (2013) }\end{array}$ & $\begin{array}{l}\text { Paropakar } \\
\text { Maternity } \\
\text { and Women's } \\
\text { Hospital, } \\
\text { Kathmandu }\end{array}$ & $\begin{array}{l}4394 \\
\text { deliveries } \\
\text { with } 186 \\
\text { neonatal } \\
\text { sepsis }\end{array}$ & $\begin{array}{l}\text { Haematological } \\
\text { scoring system }\end{array}$ & $\begin{array}{l}\text { Oct - Dec } \\
2011\end{array}$ & $\begin{array}{l}\text { Hospital } \\
\text { based }\end{array}$ & $4.23 \%$ & $\begin{array}{l}\text { Cesarean section, } \\
\text { Apgar score }<4 \\
\text { at } 1 \text { min and } \\
<7 \text { at } 5 \text { min of } \\
\text { birth }(p=0.001) \\
\text { predicted sepsis. }\end{array}$ \\
\hline $\begin{array}{l}\text { Sharma } \\
\text { A et al. } \\
(2011)\end{array}$ & $\begin{array}{l}\text { Nepal Medical } \\
\text { College, } \\
\text { Kathmandu }\end{array}$ & $\begin{array}{l}793 \text { deliveries } \\
\text { with } 26 \\
\text { neonatal } \\
\text { sepsis }\end{array}$ & Not mentioned & $\begin{array}{l}\text { April } \\
\text { 2008- } \\
\text { April } 2009\end{array}$ & $\begin{array}{l}\text { Hospital } \\
\text { based }\end{array}$ & $3.28 \%$ & - \\
\hline $\begin{array}{l}\text { Khanal } \\
\text { S et al. } \\
(2011)\end{array}$ & $\begin{array}{l}\text { Morang } \\
\text { District }\end{array}$ & $\begin{array}{l}11457 \text { live } \\
\text { births with } \\
1051 \text { PSBI } \\
\text { cases }\end{array}$ & MINI algorithms & $\begin{array}{l}\text { May 2005- } \\
\text { April } 2007\end{array}$ & $\begin{array}{l}\text { Community- } \\
\text { based }\end{array}$ & $9.17 \%$ & - \\
\hline $\begin{array}{l}\text { Shrestha } \\
\text { S et al. } \\
(2010)\end{array}$ & $\begin{array}{l}\text { Patan } \\
\text { Hospital, } \\
\text { Patan }\end{array}$ & $\begin{array}{l}7117 \text { live } \\
\text { births with } \\
161 \text { neonatal } \\
\text { sepsis }\end{array}$ & Blood culture & $\begin{array}{l}\text { Nov. } \\
2006-\text { Nov } \\
2007\end{array}$ & $\begin{array}{l}\text { Hospital } \\
\text { based }\end{array}$ & $2.26 \%$ & - \\
\hline
\end{tabular}


We cannot ascertain the denominators mentioned in the hospital-based studies where live births were mentioned for the particular studies because the number of neonates that were admitted due to referral was not mentioned in the articles. Except in study by Thapa B et al. none of the studies have further analysed the association between the neonatal sepsis/PSBI and risk factors. ${ }^{16}$ The prevalence of neonatal sepsis in hospital-based studies ranged from $2.3 \%$ to $4.2 \%$ with least prevalence in Patan Hospital followed by Nepal Medical College and highest in Paropakar Maternity and Women's Hospital. The prevalence of PSBI in the community-based study was 9.2\% (Table 1).

\section{DISCUSSION}

The review found that a small number of studies have been conducted on the true prevalence of Neonatal sepsis and PSBI in Nepal. The prevalence of neonatal sepsis in the hospital-based study ranged from $2.3 \%$ to $4.2 \%$ and the prevalence of PSBI in the community-based study was $9.2 \%$.

As mentioned previously, most studies explored blood culture-proven neonatal sepsis among the suspected neonates which did not give the true prevalence of the morbidity. However, it is important to note that the prevalence of culture-proven neonatal sepsis among the suspected neonates is very high in Nepal ranging from $15 \%$ to as high as more than $50 \% .{ }^{19-23}$ In a systemic review done to estimate possible severe bacterial infection in neonates in Sub-Saharan Africa, South Asia, and Latin America for 2012, the pooled estimate of PSBI incidence risk was $7.6 \%(95 \% \mathrm{Cl} 6.1-9.2 \%) .{ }^{24}$

Neonatal infections, the single largest cause of neonatal mortality globally, is preventable with existing evidence-based, cost-effective interventions. ${ }^{25-27}$ Simple interventions such as hand washing and limiting the number of visitors handling the neonates can reduce significant proportion of $\mathrm{PSBI} /$ neonatal sepsis. ${ }^{28-32}$ Prevention of maternal infections (tetanus toxoid vaccination), neonatal infections (Clean delivery and Chlorhexidine gel application to cord after delivery), early breastfeeding, early recognition of illness, and appropriate management of PSBI and neonatal sepsis are essential to reduce neonatal mortality and long-term disability. ${ }^{33-36}$

It is interesting to note the wide variation in community and hospital reported prevalence of PSBI and neonatal sepsis in the studies reviewed. This could be due to variations in the aims and objectives of the studies, diagnostic criteria and in sample selection procedures, the types of samples studied, instruments and questionnaires used for data collection. The articles included in this review were very less, hence it may not be generalised to the whole country. It is also possible that some studies, which were published in journals not indexed in PUBMED and NEPJOL, could not be identified.

The present review is the only attempt that has so far been made to find out the true prevalence of sepsis and PSBI among neonates in Nepal. This review provides useful information about the quality and quantity of studies conducted on this issue in Nepal and may help to identify further areas for research in this field.

\section{CONCLUSIONS}

From this review, it is clear that to date very few studies have been conducted attempting to find out the true prevalence of sepsis and PSBI among the general population in Nepal. There is a need to conduct a nationwide survey on the prevalence of sepsis and PSBI among neonates and compare within and outside countries, which may help to evaluate health system performance and make appropriate health policy. There is also an urgent need to seek for the risk factors and test the intervention for the benefit of the sick neonates so as to achieve the Nepal ENAP goal.

\section{ACKNOWLEDGEMENTS}

The authors would like to thank Dr Puja Sharma and Dr Puja Chaurasia for their help in editing the manuscript. Views presented in this article are of the authors and not of the organizations they represent.

\section{REFERENCES}

1. Million Death Study Collaborators. Causes of neonatal and child mortality in India: a nationally representative mortality survey. Lancet. 2010 Dec 3;376(9755):185360.[PubMed]

2. Seale AC, Blencowe H, Zaidi A, Ganatra H, Syed S, Engmann C, et al. Neonatal severe bacterial infection impairment estimates in South Asia, sub-Saharan Africa, and Latin America for 2010. Pediatr Res. 2013 Dec;74(Suppl 1):73.[PubMed]

3. Watson RS, Carcillo JA. Scope and epidemiology of pediatric sepsis. Pediatr Crit Care Med. 2005 May $1 ; 6(3):$ S3-5.[PubMed]

4. Liu L, Johnson HL, Cousens S, Perin J, Scott S, Lawn JE, Rudan I, Campbell H, Cibulskis R, Li M, Mathers C. 
Global, regional, and national causes of child mortality: an updated systematic analysis for 2010 with time trends since 2000. Lancet. 2012;379(9832):2151-61.[PubMed]

5. Manandhar SR, Ojha A, Manandhar DS, Shrestha B, Shrestha D, Saville N, Costello AM, Osrin D. Causes of stillbirths and neonatal deaths in Dhanusha district, Nepal: a verbal autopsy study. Kathmandu Univ Med J. 2010;8(29):62.[PubMed]

6. Lawn JE, Cousens S, Zupan J. Neonatal survival 1.4 million neonatal deaths: When? Where? Why? Lancet. 2005;365(9462):891-900.[PubMed]

7. World Health Organization (WHO). Guideline: managing possible serious bacterial infection in young infants when referral is not feasible. Geneva:WHO; 2015.[PubMed]

8. Singer M, Deutschman CS, Seymour CW, Shankar-Hari $\mathrm{M}$, Annane D, Bauer M, et al. The third international consensus definitions for sepsis and septic shock (sepsis-3). JAMA. 2016;315(8):801-10.[PubMed]

9. Gove S. Integrated management of childhood illness by outpatient health workers: technical basis and overview. The WHO Working Group on Guidelines for Integrated Management of the Sick Child. Bull World Health Organ. 1997;75(Suppl 1):7.[PubMed]

10. Khatri RB, Mishra SR, Khanal V, Gelal K, Neupane S. Newborn health interventions and challenges for implementation in Nepal. Front Public Health. 2016;4:15. [PubMed]

11. Ministry of Health Nepal, New ERA, ICF. Nepal Demographic and Health Survey 2016: Key Indicators. Kathmandu, Nepal: Ministry of Health, Nepal 2017. [Full Text]

12. World Health Organization. Every Newborn: an action plan to end preventable deaths. [Full Text]

13. Kinney MV, Cocoman O, Dickson KE, Daelmans B, Zaka N, Rhoda NR, et al. Implementation of the every newborn action plan: progress and lessons learned. ISemin Perinatol. 2015;39(5): 326-37.[PubMed]

14. Guo S, Rafique N, You D, Noble DJ. Progress in south Asia after the launch of the Global Every Newborn Action Plan. Lancet Glob Helth. 2016;4(10):e682-3.[PubMed]

15. Sharma A, Rijal P, Bichha RP. Neonatal status in Nepal Medical College Teaching Hospital. Nepal Med Coll J. 2011;13(3):197-8.[PubMed]
16. Thapa B, Thapa A, Aryal DR, Thapa K, Pun A, Khanal $S$, et al. Neonatal sepsis as a major cause of morbidity in a tertiary center in Kathmandu. J Nepal Med Assoc. 2013;52(192):549-56.[PubMed]

17. Shrestha S, Adhikari N, Rai BK, Shreepaili A. Antibiotic resistance pattern of bacterial isolates in neonatal care unit. J Nepal Med Assoc. 2010;50(180).[PubMed]

18. Khanal S, Jaganath Sharma VS, Dawson P, Houston R, Khadka N, Yengden B. Community health workers can identify and manage possible infections in neonates and young infants: MINI - a model from Nepal. J Health Popul Nutr. 2011;29(3):255-64.[PubMed]

19. Shrestha R, Shrestha JM, Gurung B. Antibiotic Usage and its Sensitivity Pattern in the NICU. Kathmandu Univ Med J. 2013;10(2):27-32.[PubMed]

20. Shaw CK, Shaw P, Thapalial A. Neonatal sepsis bacterial isolates and antibiotic susceptibility patterns at a NICU in a tertiary care hospital in western Nepal: a retrospective analysis. Kathmandu Univ Med J. 2007;5(2):153-60 [PubMed]

21. Shrestha S, Singh SD, Shrestha NC, Shrestha RP, Madhup SK. Comparision of clinical and laboratory parameters in culture proven and unproven early onset sepsis in NICU. Kathmandu Univ Med J. 2015;11(4):310-4.[PubMed]

22. Chapagain RH, Acharya R, Shrestha N, Giri RB, Bagale BB, Kayastha M. Bacteriological Profile of Neonatal Sepsis inNeonatal Intermediate Care Unit of Central Paediatric Referral Hospital in Nepal. J Nepal Health Res Counc. 2015;13(31):205-8.[PubMed]

23. Shrestha P, Das BK, Bhatta NK, Jha DK, Das B, Setia A, et al. Clinical and bacteriological profiles of blood culture positive sepsis in newborns. Journal of Nepal Paediatric Society. 2007;27(2):64-7.[Full Text]

24. Seale AC, Blencowe H, Manu AA, Nair H, Bahl R, Qazi $\mathrm{SA}$, et al. Estimates of possible severe bacterial infection in neonates in sub-Saharan Africa, south Asia, and Latin America for 2012: a systematic review and meta-analysis. Lancet Infect Dis. 2014;14(8):731-41.[PubMed]

25. Lawn JE, Wilczynska-Ketende K, Cousens SN. Estimating the causes of 4 million neonatal deaths in the year 2000. Int J Epidemiol. 2006;35(3):706-18.[PubMed]

26. Lassi ZS, Salam RA, Das JK, Bhutta ZA. Essential interventions for maternal, newborn and child health: background and methodology. Reprod Health. 2014;11(1):S1.[PubMed] 
27. Darmstadt GL, Bhutta ZA, Cousens S, Adam T, Walker N, De Bernis L. Lancet Neonatal Survival Steering Team. Evidence-based, cost-effective interventions: how many newborn babies can we save?. Lancet. 2005;365(9463):977-88.[PubMed]

28. Pessoa-Silva CL, Hugonnet S, Pfister R, Touveneau S, Dharan S, Posfay-Barbe K, et al. Reduction of health careassociated infection risk in neonates by successful hand hygiene promotion. Pediatrics. 2007;120(2):e382-90. [PubMed]

29. Lam BC, Lee J, LauYL. Hand hygiene practices in a neonatal intensive care unit: a multimodal intervention and impact on nosocomial infection. Pediatrics. 2004;114(5):e56571.[PubMed]

30. Won SP, Chou HC, Hsieh WS, Chen CY, Huang SM, Tsou $\mathrm{KI}$, et al. Handwashing program for the prevention of nosocomial infections in a neonatal intensive care unit. Infect Control Health Epidemiol 2004;25(9):742-6. [PubMed]

31. Webster J, Pritchard MA. Gowning by attendants and visitors in newborn nurseries for prevention of neonatal morbidity and mortality. Cochrane Database Syst Rev. 2003. [PubMed]
32. Cook R, Gupta GK. The MassGeneral Hospital for Children Handbook of Pediatric Global Health. Springer. 2014: 87-94. [Full Text]

33. Seward N, Osrin D, Li L, Costello A, Pulkki-Brännström AM, Houweling TA, et al. Association between clean delivery kit use, clean delivery practices, and neonatal survival: pooled analysis of data from three sites in South Asia. PLoS Med. 2012;9(2):e1001180.[PubMed]

34. Edmond K, Zaidi A. New approaches to preventing, diagnosing, and treating neonatal sepsis. PLoS Med. 2010;7(3):e1000213.[PubMed]

35. Tielsch JM, Darmstadt GL, Mullany LC, Khatry SK, Katz J, LeClerq SC, et al. Impact of newborn skin-cleansing with chlorhexidine on neonatal mortality in southern Nepal: a community-based, cluster-randomized trial. Pediatrics. 2007;119(2):e330-40. [PubMed]

36. Mullany LC, Katz J, Li YM, Khatry SK, LeClerq SC, Darmstadt GL, et al. Breast-feeding patterns, time to initiation, and mortality risk among newborns in southern Nepal. J Nutr. 2008;138(3):599-603.[PubMed] 